\title{
DEVELOPING THE ARCHAEBACTERIA AND EUBACTERIA WEB-BASED LEARNING MEDIA FOR HIGH SCHOOL STUDENTS
}

\author{
Maulida Ulfa Hidayah*, Sonja V.T Lumowa, and Didimus Tanah Boleng \\ Department of Biology Education, Mulawarman University, Samarinda, East Kalimantan, Indonesia \\ *Corresponding e-mail: maul.yda.93@gmail.com
}

\begin{abstract}
The $21^{\text {st }}$-century biology learning requires technology-based learning which is potential for improving students' learning outcomes. This research aimed to examine the validity and effectiveness of web-based learning media on Archaebacteria and Eubacteria on the learning process. This web-based learning media was structured by using 4-D Thiagarajan model. The research was conducted at three SSHSs of Samarinda. The data were obtained from validators' (media expert, material expert, and linguist), teachers', and students' opinion by using questionnaire; while the effectiveness was determined based on students' test score and their response. The results showed that the web-based learning media was very valid with the average score from experts as high as $95.27 \%$. Moreover, this media has been proven to improve the student's cognitive learning outcomes (gain score 0.39) and well responded by both teachers and students.
\end{abstract}

Keywords: Archaebacteria, Eubacteria, web-based media

(C) 2018 Department of Biology Education, FTTE, University of Muhammadiyah Malang, Indonesia

\section{INTRODUCTION}

Education is a conscious and planned effort to hold an active learning process aimed at developing the learners' potency. Educational activities are also a process of empowering the personality of learners who are able to support the life of the community. Furthermore, Kurniawan (2015) stated education is conscious and systematical effort carried out by people who are given the responsibility to educate learners to be individuals that have characters and behavior that are in line with the educational aim.

Learning is an interactive process among learner, educator, and learning material in the learning environment. In the process, various messages delivered from teachers to students (Shaimah, 2016). Through this process, teachers try to educate learners to meet the educational aims that have been set (Sudjana, 2017).

The transfer of messages to learner will be more effective if the learning process utilizes learning media. According to Sanjaya (2012), media is medium to transfer message or information from source to receiver. Moreover, the existence of learning media is reported to improve students' understanding (Amris,
Akhyar, \& Haenilah, 2015) and motivation (Widiansyah, Indriwati, Munzil, \& Fauzi, 2018). Moreover, lack of media in some material make student understanding of that material is not good (Mupa \& Chinooneka, 2015).

Beside the existence of media, learning oriented to the needs of the 21st-century is also essential. The learning that prepares students to face the challenges of 21 st-century needs to be done to develop the various capabilities students need in the current century (Pantiwati \& Permana, 2017; Permana, 2015). Correspondingly, the 21st-century biology learning requires technology-based learning which is potential for improving students' learning outcomes. However, according to observation results conducted by a researcher at 3 different schools, the learning process in State Senior High School (SSHS) 1 of Balikpapan, SSHS 2 of Balikpapan and SHS Patra Dharma of Balikpapan held not as expected. Some of the students did not give attention to the lesson, some students more concerned with an unessential matter, and the majority of students just remember the fact from the book. In these schools, biology teachers sometimes have a problem in delivering teaching material. Some 
of those problems were due to the diversity of students; cognitive ability and there was no suitable media to visualize some of the biological material. This condition revealed during teacher taught Archaebacteria and Eubacteria topic.

Through interviews, it was revealed that student perceived difficulty to understand Archaebacteria and Eubacteria concepts due to the concepts are abstract. This condition in line with Khotimah (2014) who informed student get difficult to understand the concept of microscopic learning objects such as Archaebacteria and Eubacteria. The result of an interview with the teachers also shows that teacher also perceived difficulty to teach Archaebacteria and Eubacteria. The difficulty in teaching Archaebacteria and Eubacteria is about how to make the student understand bacterial structure and classification. Moreover, the lack of interesting media has made Archaebacteria and Eubacteria topic more difficult to teach. The lack of interesting media causing problems to teach Archaebacteria and Eubacteria topic (Eady \& Lockyer, 2013; Hew \& Brush, 2007; Murnane \& Jennifer, L, 2007).

Besides the information about students' learning difficulties, the other information revealed was students were very interest in accessing the internet. On the one hand, students are less interested in studying Archaebacteria and Eubacteria topics, on the other hand, students are very interested in accessing the internet. Therefore, the existence of internet-based media can be used as an alternative solution to the problem faced by students. Moreover, internet-based media can facilitate student to understand abstract concepts and non-direct visualized many microscopic objects. One of internet-based media is web-based learning media.

Various benefits from the utilization of webbased learning media have been reported by some previous researches, such as could improve students' motivation and learning outcomes, improving critical thinking (Wahyuni \& Muttaqin, 2018), satisfaction in the learning process, and better retention in the learning topic (Saini, Abdul, \& Purohit, 2014). However, the development of web-based media on Archaebacteria and Eubacteria topic is still hard to find in Indonesia. In fact, some of the previously mentioned research (Saini et al., 2014; Wahyuni \& Muttaqin, 2018) are research that conducted not on biological subjects.
Moreover, related to Archaebacteria and Eubacteria topic, research in Indonesia have been more frequently examined the influence of various models of learning on improving student learning outcomes on the topic (Cahyasari \& Haryanti, 2016; Nurinayah \& Putra, 2015). Thus, the development and the implementation of web-based learning media in biology subject need to be conducted. Therefore, this research aims to 1) examine the validity of web-based biology learning media on Archaebacteria and Eubacteria; and 2) examine its effect on the learning process.

\section{METHOD}

This research was adapting 4D-Thiagarajan development model (Thiagarajan, Semmel, D, \& Semmel, M, 1974). The research stage consist of define, design, develop, and disseminate. Define stages was conducted from front-end analysis to specifying instructional objectives. Front-end analysis was conducted through interview and questionnaire filling by the teacher, as well as observation activities to find out the information about learning problems and school facilities and infrastructures. Learner analysis was conducted through questionnaire filling by 30 Class $\mathrm{X}$ students from SHS Patra Dharma, SSHS 1, and SSHS 2 of Balikpapan. Task and concept design for web-based media based on literature review (task and concept analysis). After that, instructional objectives were formulated.

Design stages divided into two steps. The first step was the media and format selection and the second step was the initial design. In the initial design, researcher set framework structure of web-based learning media, start from material systematical presenting, illustration, visualization and evaluation tool design, until writing initial product draft according to basic competencies. After that, the design of storyboard, learning set, and material support for media were made. Web-based media is developed in this stage including text writing, setting up picture and video, making a mailing list, hyperlink and evaluation tool.

In the developing stage, the prototype of web-based learning media validated by material experts, learning media expert, and linguist. In the developing stage, the limited trial was also conducted. The population of this research was all Class X SSHS at Balikpapan and sample of this research were grade X SSHS at SSHS 1, 
SSHS 2, and SHS Patra Dharma of Balikpapan. The limited trial was conducted to examine student understanding of the content of the web-based media. Class X-4 SSHS was chosen as an experimental class and Class $\mathrm{X}-5$ at the SHS Patra Dharma of Balikpapan was chosen as a control class. After the learning process, student filled respond questionnaire.

Then, disseminate stage was conducted through conducting large group trial. The webbased media from limited trial then tested to a large group test. Class X-4 at the SSHS 1 of Balikpapan and Class X-6 at the SSHS 2 of Balikpapan were chosen as an experimental class, while class X-3 SSHS 1 of Balikpapan and X-3 SSHS 2 of Balikpapan were chosen as control class. After the learning process, student filled the respond questionnaire.

Research instruments that used in this research were: 1) questionnaire for learning that was used to obtain the information about the students' responds on learning process; 2) observational sheet that was used to obtain the information about school learning facilities that used in the learning process; 3) expert validation questionnaire that was used to know about the properness of the learning media; 4) student respond questionnaire that was used to know about the student interest and respond to the learning media; and 5) teacher respond questionnaire that was used to know the teacher respond to the learning media and process.

Some data that has been collected in this research were the result of validation from experts, students' learning outcomes, student respond questionnaire, and teacher respond.

\section{The result of validation from experts}

Every single question in the questionnaire has 1-4 option: 1 (not valid), 2 (valid enough), 3 (valid), and 4 (very valid). All of the score that has been collected than being calculated to percentage form. The formula to calculate the data can be seen in Formula 1.

$$
K=\frac{F}{N x R} x 100 \%
$$

Description:

$\mathrm{K}=$ Media properness $(\%)$;

$\mathrm{F}=$ Sum of respondent answers;

$\mathrm{N}=$ Highest score;

$\mathrm{R}=$ Sum of all item from respondents
All of the average scores that given by the experts were compared with the categories presented in Table 1.

Table 1. Percentage range and qualitative criterion media properness test by experts

\begin{tabular}{cl}
\hline Range (\%) & Qualitative criterion \\
\hline $82-100$ & Very valid \\
$63-81$ & Valid \\
$44-62$ & Valid enough \\
$25-43$ & Not valid \\
\hline
\end{tabular}

(Source: Adopted from Sudjana, 2010).

\section{Students' learning outcomes}

All of the pretest data then being tested using Analysis of Variance (ANOVA) after fulfilling all of the assumption tests. After conducted the lesson Archaebacteria and Eubacteria there was posttest. To know the increasing cognitive score from the student, pretest and posttest data then calculated using $\mathrm{N}$-gain. The equations used to calculated $\mathrm{N}$-gain presented in Formula 2.

$$
<\mathrm{g}>=\frac{\text { Spost }-S p r e}{S_{\text {maks }}-S_{p r g}}
$$

Description: $g=\mathrm{N}$-gain

There are 3 categories in the gain score. They are high $((<\mathrm{g}\rangle)>0.7)$, moderate $(0.3 \leq$ $(<\mathrm{g}>) \leq 0.7$ and low $((<\mathrm{g}>)<0.3)$. If the gain score is in the moderate or high category, the learning media is giving positive impact to the students' learning outcomes.

\section{Student respond questionnaire}

Every single question in the questionnaire consist of 1-4 option: 1 for do not agree, 2 for agreeing enough, 3 for agree, and 4 for very agree (Table 2).

Table 2. Student respond questionnaire

\begin{tabular}{lcc}
\hline \multirow{2}{*}{ Likert Scale } & \multicolumn{2}{c}{ Score } \\
\cline { 2 - 3 } & $\begin{array}{l}\text { Positive } \\
\text { Statement }\end{array}$ & $\begin{array}{l}\text { Negative } \\
\text { Statement }\end{array}$ \\
\hline SS (Strongly Agree) & 4 & 1 \\
S (Agree) & 3 & 2 \\
TS (Disagree) & 2 & 3 \\
STS (Strongly Disagree) & 1 & 4 \\
\hline
\end{tabular}

(Source: Arikunto, 2009).

Then, all of the score is calculated using equations presented in Formula 3.

$p=\frac{f}{N} x 100 \%$ 
Description:

$\mathrm{p}=$ Score percentage;

$\mathrm{F}=$ Sum of score by student;

$\mathrm{N}=$ Sum all of maximum score

After that, $\mathrm{P}$ value being compared with the categories presented in Table 3.

Table 3. Percentage range and qualitative test criterion by student

\begin{tabular}{cc}
\hline Range (\%) & Qualitative criterion \\
\hline $81-90$ & Very valid \\
$71-80$ & Valid \\
$61-70$ & Valid enough \\
$50-60$ & Not valid \\
\hline
\end{tabular}

(Source: Adapted from Sudjana, 2010).

\section{Teacher respond}

The teacher respond toward learning media was qualitative obtained from questionnaire.

\section{RESULTS AND DISCUSSION}

\section{Validity to experts and product revision}

The validation results by a material expert is presented in Table 4 and showed that webbased learning media was very valid $(95.5 \%)$.

Table 4. The result of web-based media validation by material expert

\begin{tabular}{cccc}
\hline No & $\begin{array}{c}\text { Evaluation } \\
\text { Aspect }\end{array}$ & $\begin{array}{c}\text { Percentage } \\
(\boldsymbol{\%})\end{array}$ & Criterion \\
\hline 1 & Learning & 97.5 & Very valid \\
2 & Content & 94.2 & Very valid \\
\hline Average & 95.9 & Very valid \\
\hline \multirow{2}{*}{ Test decision } & $\begin{array}{l}\text { Very valid, revision not } \\
\text { required }\end{array}$ \\
\hline
\end{tabular}

There were some suggestions by material expert before revision: 1) web media has to be adapted and be clarified so that user can feel the difference between using conventional learning media and web-based learning media, 2) repair the bibliography, 3) adjust content and syllabus, 4) learning stages at Learning Design has to be adjusted to the syllabus, 5) evaluation question has to be adjusted to the learning indicator, 6) assessment rubric should be attached to the Learning Design, 7) show the difference between conventional learning process and web-based learning in syllabus, 8) write web address in the learning source at syllabus, and 9) activity in student worksheet should be adjusted to the learning strategy.

The results of validation by media expert is presented in Table 5 . The suggestions by media expert before revision were 1) change the address of web so that could be remembered easily, 2) change the font type, and 3) source of the content in the web should be come from a valid source.

The result of validation by linguist is presented in Table 6. Linguist expert assesses the aspect of simplicity, communicative and interactivity dialogue, and conformity with the development of the learner. Based on Table 6, the web-based learning media is very valid $(100 \%)$. Suggestions by linguist before the revision was the media content need to change some proposition of the web.

Table 5. Result of web-based media validation by media expert

\begin{tabular}{|c|c|c|c|}
\hline No & $\begin{array}{c}\text { Evaluation } \\
\text { Aspect }\end{array}$ & $\begin{array}{c}\text { Percentage } \\
(\%)\end{array}$ & Criterion \\
\hline 1 & Technic & 95.0 & Very valid \\
\hline 2 & Design & 83.3 & Very valid \\
\hline 3 & Interactivity & 87.5 & Very valid \\
\hline & Average & 88.6 & Very valid \\
\hline & Decision & \multicolumn{2}{|c|}{$\begin{array}{l}\text { Very valid, revision not } \\
\text { required }\end{array}$} \\
\hline
\end{tabular}

Table 6. Result of web-based media validation by linguist

\begin{tabular}{clcc}
\hline No & \multicolumn{1}{c}{$\begin{array}{c}\text { Evaluation } \\
\text { Aspect }\end{array}$} & $\begin{array}{c}\text { Percentage } \\
(\mathbf{\%})\end{array}$ & Criterion \\
\hline 1 & $\begin{array}{l}\text { Simplicity } \\
\text { Communicative } \\
\text { and Interactivity } \\
\text { Dialogue } \\
\text { Conformity with } \\
\text { Development of } \\
\text { Learner }\end{array}$ & 100 & $\begin{array}{l}\text { Very valid } \\
\text { Very valid }\end{array}$ \\
Average & 100 & Very valid \\
\hline Test decision & $\begin{array}{l}\text { Very valid, revision not } \\
\text { required }\end{array}$ \\
\hline
\end{tabular}

Based on the experts' recommendation, some revision was carried out on web-based learning media. Some revision according to the experts was about changes to the web address, changes of font type, and changes of the content source. The final form of the website can be seen at Figure 1.

From all validation result by experts, the lowest score was a score from media expert, especially on design aspect (see Table 5). Based on the validation result, one component that should be improves was on web components. The web components are including display of layout, font and size design, picture layout, video animation, and feasibility of web. Those components still did not reach maximum score. If those components could be improved based 
on recommendation notes from media expert, the web-based learning media would become more effective learning media. This statement is in line with Saad (2004) who explained the learning media which have good layout design and user-friendly will become an effective learning media for students.

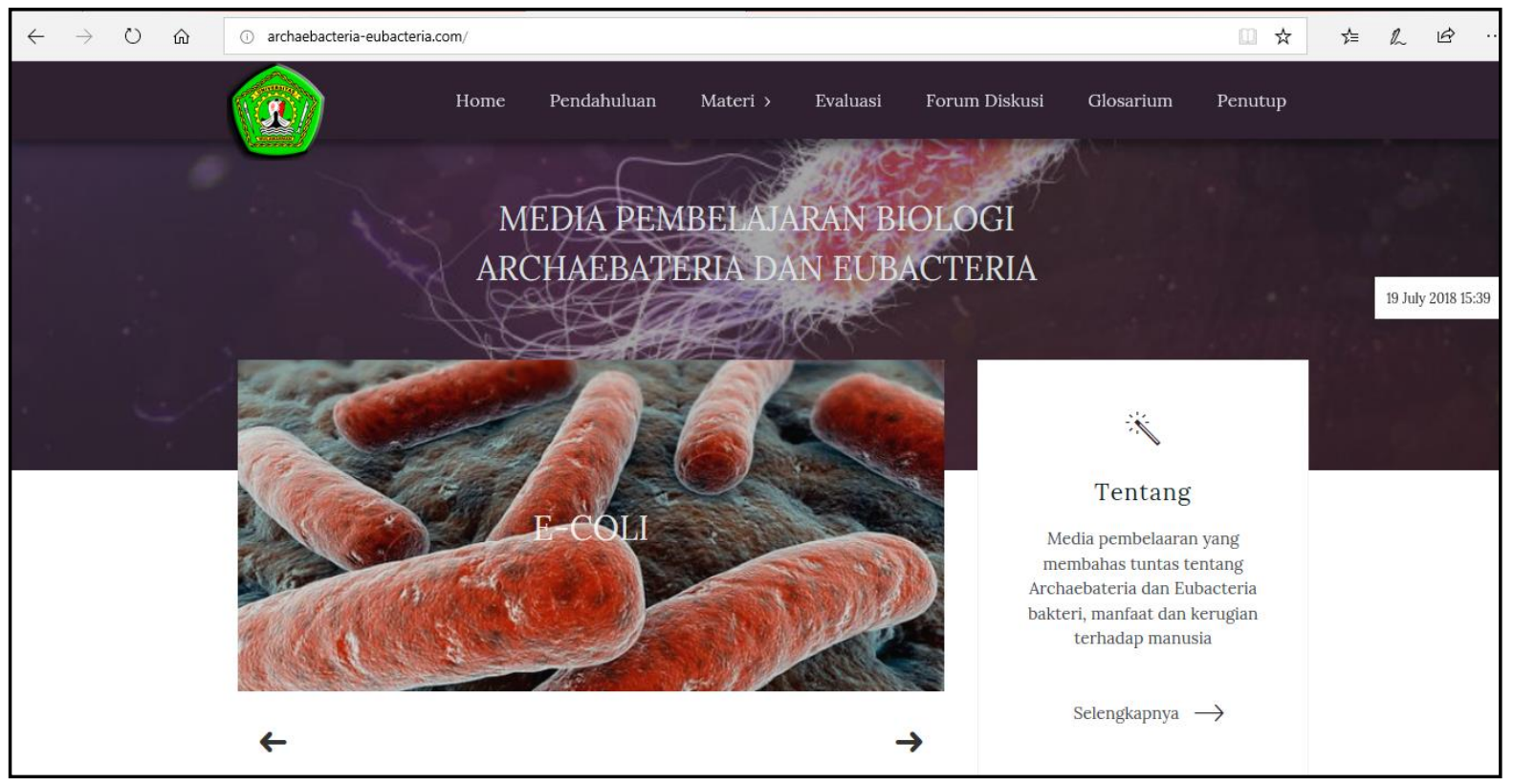

Figure 1. The final form of the learning media website (http://archaebacteria-eubacteria.com/)

The highest score from media expert was in the technic component. Based on validation results, almost all of the indicator in the technic component was perfect (adjust to the perfect criterion). If a learning media is fulfilling of layout criterion, the media will easy to be used by students (Pantiwati, Wahyuni, \& Permana, 2017; Saad, 2004). Then, media expert suggest, it would be better if web address was changed to a web address that easy to remember by students. Media expert also recommends changing the kind and size of the font. These change are to attract the user's attention (Knight \& Glaser, 2013), make users faster to read content of the writing (Purwanti \& Permana, F, 2018; Sihombing, 2015), as well as easy to read by reader due to there is adjustability between message and style of the writing in the web (Bonneville, 2011; Kartika, 2015).

Validation result from linguist was the highest one $(100 \%)$. All of the information written on the web was easy to understand and adjust to the aim of the web making. Besides that, the web-based learning has "Glosarium" (Glossary) so users can understand the meaning of important terms that used in the web. Linguist suggestion was to fix some of the preposition in the web content. Change of preposition aimed to make learning media become more efficient (Amalia, 2017) and meaningful sentence (Rehatta, 2014).

Validation by material expert shows that web-based media learning was very valid (table 4). Adjustable between material in media and aim of the learning process, possibility to understand by students and profundity of the material need to be improved. This revision needs to be done to make sure that the content of the media was valid, reliable, and make webbased learning media become an effective learning media to use in the learning process.

\section{Limited trial phase}

In this phase, the result of gain score calculation shows that the experimental class score was 0.31 (medium category) while control class was 0.22 (low category). Based on the result, it indicates that the improvement of learning outcomes in experimental class that used web-based learning media in the learning process was higher than the control class.

The implementation of web-based learning media may make students felt more interest in the learning process. This condition will affect the motivation of students in the experimental class was higher than in the control class. The existence of learning media based on the website would also facilitate students to search 
more information, and then more think about the course material (Lane \& Lane, A, 2001; Liu, Olmanson, \& Horton, 2011; Schunk, Meece, \& Pintrich, 2015). Moreover, the content of the web is varied so that students not only focus on the teacher or in an easy submaterial of the course, but students also could access an unknown learning material or difficult concept using available internet connection (Amris et al., 2015; Oftika, Jalmo, \& Marpaung $\mathrm{R}, 2015$ ).

Web-based learning media was design to improve/develop student cognitive and psychomotor skill. The media could improve those learning outcomes due to students were facilitate to has a prior knowledge of the material. After looking the video, students get the main idea of video and transform it to the action (Razak \& Hua, 2012) and students who learn using web-based media may open the video frequently just than conventional class so that they can memorize the concepts (Salyers, 2007). Memorize the concepts is an essential goal during the learning process (Ramadani, Fauzi, Sukmawati, \& Corebima, 2015; Sukmawati, Ramadani, Fauzi, \& Corebima, 2015).

Besides that, in the cognitive field, students who learn using web-based learning possibility has a higher motivation to learn and better understand about the material (because learning material divided into a small part in the web) (Salyers, 2007). Video on the web can be reply over time so it can easier for the student to understand step by step on making something which is appropriate to the learning process. Moreover, the list of questions in "Discussion" on the web also made student think more creative using their high order thinking skills.

\section{Student respond questionnaire}

The result of student respond questionnaire (assessment to the learning process and webbased learning media) is presented in Table 7 . Based on Table 7, web-based learning media has a well respond from the students $(87.1 \%)$.

The result of validation from experts, limited trial phase, and student respond questionnaire showed the learning process using web-based learning media that has been developed very valid. Therefore, the research continued to the large group trial phase.
Table 7. Result of student responds questionnaire SHS Patra Dharma Balikpapan

\begin{tabular}{cccc}
\hline No & $\begin{array}{c}\text { Evaluation } \\
\text { Aspect }\end{array}$ & $\begin{array}{c}\text { Percentage } \\
(\boldsymbol{\%})\end{array}$ & Criterion \\
\hline 1 & Technic & 89.0 & Very valid \\
2 & Design & 87.3 & Very valid \\
3 & Material/content & 85.2 & Very valid \\
4 & Learning & 86.9 & Very valid \\
& Motivation & & \\
\hline Average & 87.1 & Very valid \\
\hline \multirow{2}{*}{ Test decision } & Very valid, revision not \\
\end{tabular}

\section{Effectiveness test (large group trial phase)}

The result of students' respond questionnaire in large group trial phase is presented in Table 8.

Table 8. Result of student responds questionnaire SSHS 1, and SSHS 2 Balikpapan

\begin{tabular}{|c|c|c|c|}
\hline No & $\begin{array}{c}\text { Evaluation } \\
\text { Aspect }\end{array}$ & $\begin{array}{c}\text { Percentage } \\
(\%)\end{array}$ & Criterion \\
\hline 1 & Technic & 87.0 & Very valid \\
\hline 2 & Design & 86.4 & Very valid \\
\hline 3 & Material/content & 83.5 & Very valid \\
\hline 4 & $\begin{array}{l}\text { Learning } \\
\text { Motivation }\end{array}$ & 81.6 & Very valid \\
\hline \multicolumn{2}{|c|}{ Average } & 84.6 & Very valid \\
\hline \multicolumn{2}{|c|}{ Test Decision } & $\begin{array}{l}\text { Very valid, } \mathrm{r} \\
\text { required }\end{array}$ & vision not \\
\hline
\end{tabular}

Based on Table 8, the respond of students on the implementation of web-based learning media during learning process was well responded $(87.1 \%)$. This result was inlined with a limited trial phase that has been mentioned earlier. Thus, the result confirmed that the application of web-based learning media that has been developed in this study was highly recommended in the learning process.

On another parameter, based on large group trial phase results, the implementation of webbased learning media could also improve students' learning outcomes. However, the gain score of the experimental class seems similar with a gain score of the control class. Based on the calculation, the gain score of the experimental class was 0.38 while the gain score of the control class was 0.34. Both the experimental class and control class have again scored in the medium category. After conducting ANOVA test, the improvement of students' learning outcomes between both classes did not differ significantly. 
The result that showed there was no significant difference in students' learning outcomes between the two class probably caused of some reasons. First, students in the control class may have the big curiosity to find out learning material although they do not use web-based learning media. Second, all of the students in the experimental and control class has the same motivation level for studying biology concepts. Therefore, the utilization of web-based learning media or not in both classes did not make a significant difference in their learning outcomes improvement. Another reason for this difference could be about their response to the media. Although there was no significant difference between both classes, it can be seen that the experimental class still has a higher score than the control class. This fact shows that an experimental class that uses webbased learning still got higher gain score than the control class. This condition indicates the implementation of web-based learning media was more effective to improve student learning outcomes.

According to the results of validation by experts, limited trial phase, as well as large group trial phase, web-based learning media was fulfilled the properness criterion and could improve the effectiveness of learning process. However, there are some contradictions about the implementation of web media learning during the learning process. But, there is a contradiction, such as the development or the implementation of web-based learning media need more money. This condition becomes a technical barrier during the learning process, besides sometimes the development of webbased learning media should pay attention about the appropriate media/technology barrier (Cook, D, 2007; Rashid, Kadiman, Zulkifli, Selamat, \& Hashim, 2016).

The other contradictions were also the implementation of web-based learning media may cause unsocial user/lack of moral value, (Arkorful \& Abaidoo, 2014; Cook, D, 2007; Rashid et al., 2016), need more preparation compared with conventional learning (Cook, D, 2007; Permana, F \& Listawati, R, 2016), hard to assess by students in several places, and less suitable in improving communication learning (Arkorful \& Abaidoo, 2014). In fact, communication skills are skills that are also needed in the 21st Century (Buku, Mite, Fauzi, Widiansyah, \& Anugerah, 2015; Huang et al., 2010)

\section{CONCLUSION}

The web-based learning media which was developed and focused on Archaebacteria and Eubacteria for senior high school was very valid/very proper with an average score from media, material, and linguist was $95.27 \%$. Moreover, this media was effective to improve student learning outcomes. In addition, the webbased learning media has improved student interest in the learning materials.

According to the research result, some suggestions are: 1) student from different school can use this media as one of learning material; 2) teacher can use this media to improve the effectiveness of learning process at Archaebacteria and Eubacteria material; 3) all teacher, students, and high education student disseminate this product widely; 4) and this media could be developing in the next stage to fulfill the requirement of learning technology.

\section{REFERENCES}

Amalia, D. (2017). Kesalahan penggunaan preposisi di dan ke serta prefiks di-dan ke- pada karangan narasi pengalaman study tour kelas VIII SMP. Universitas Muhammadiyah Surakarta.

Amris, W. S., Akhyar, F., \& Haenilah, E. Y. (2015). Pengaruh penggunaan sumber belajar terhadap prestasi belajar IPS. Universitas Lampung.

Arikunto, S. (2009). Dasar-dasar evaluasi pendidikan. Jakarta: Bumi Aksara.

Arkorful, V., \& Abaidoo, N. (2014). The role of e-learning, the advantages and disadvantages of its adoption in Higher Education. International Journal of Education and Research, 2(12), 397-410. Retrieved from http://www.ijern.com/ journal/2014/December-2014/34.pdf

Bonneville, D. (2011). How to choose a typeface. Retrieved from http://bonfx. com/how-to-choose-a-typeface/

Buku, M. N. I., Mite, Y., Fauzi, A., Widiansyah, A. T., \& Anugerah, D. Y. (2015). Penerapan pembelajaran cooperative script berbasis lesson study sebagai upaya peningkatan keaktifan lisan dan kecakapan sosial mahasiswa SI Pendidikan Biologi matakuliah strategi belajar mengajar. In Proceedings of the 2nd Seminar \& Workshop Nasional Biologi, IPA, dan Pembelajarannya 
FMIPA UM (pp. 603-606). Malang: Biologi FMIPA UM.

Cahyasari, V. D., \& Haryanti, E. H. W. (2016). Pengaruh model pembelajaran project based learning berbantu virtual laboratory terhadap peningkatan berfikir kreatif dan pemahaman konsep materi Eubacteria di SMA Negeri 8 Semarang. Bioma, 5(1), 61-74. https://doi.org/10.26877/bioma.v5i 1.1494

Cook, D, A. (2007). Web-based learning: pros, cons and controversies. Clinical Medicine, 7(1), 37-42. Retrieved from https:// www.tau.ac.il/medicine/cme/pituach/2402 10/4.pdf

Eady, M. J., \& Lockyer, L. (2013). Tools for learning: technology and teaching strategies. Learning to Teach in the Primary School. Australia.

Hew, K. F., \& Brush, T. (2007). Integrating technology into K-12 teaching and learning: current knowledge gaps and recommendations for future research. Education Tech Research Dev, 55, 223 252. https://doi.org/10.1007/s11423-0069022-5

Huang, D., Leon, S., Hodson, C., La, D., Obregon, T. N., \& Rivera, G. (2010). Preparing students for the 21st century: Exploring the effect of afterschool participation on students' collaboration skills, oral communication skills, and selfefficacy. Los Angeles. https://doi.org/10. 1037/e642072011-001

Kartika, R. (2015). Memilih dan memanfaatkan tipografi. Humaniora, Language, People, Art, and Communication Studies, 6(3), 291-42. Retrieved from http://journal. binus.ac.id/index.php/Humaniora/article/d ownload/3352/2734

Khotimah, F. N. (2014). Mengajar keterampilan psikomotorik untuk mahasiswa keperawatan menggunakan pendekatan web-enhanced: studi kuasieksperimental. UIN Syarif Hidayatullah.

Knight, C., \& Glaser, J. (2013). When typography speaks louder than words. Retrieved from https://www.smashing magazine.com/2012/04/when-typographyspeaks-louder-than-words/

Kurniawan, B. (2015). Pengembangan media pembelajaran geografi berbasis web di MAN 3 Malang. Universitas Islam Negeri Maulana Malik Ibrahim.

Lane, J., \& Lane, A, M. (2001). Self-efficacy and academic performance. Social Behavior and Personality, 29, 687-694. https://doi.org/https://doi.org/10.2224/sbp. 2001.29.7.687

Liu, M., Olmanson, J., \& Horton, L. (2011). Motivational multimedia: Examining students' learning and motivation as they use a multimedia enriched learning environment. New Orleans.

Mupa, P., \& Chinooneka, T. I. (2015). Factors contributing to ineffective teaching and learning in primary schools: Why are schools in decadence? Journal of Education and Practice, 6(19), 125-133. Retrieved from https://files.eric.ed.gov/ fulltext/EJ1079543.pdf

Murnane, R. J., \& Jennifer, L, S. (2007). What is the problem? the challenge of providing effective teachers for all children. Germany.

Nurinayah, M. H., \& Putra, A. P. (2015). Penerapan model pembelajaran berdasarkan masalah pada materi Kingdom Monera terhadap peningkatan hasil belajar dan kemampuan berpikir kritis. In Sutarno (Ed.), Prosiding Seminar Nasional XII Pendidikan Biologi: Biologi, Sains, Lingkungan, dan Pembelajarannya (pp. 248-253). Surakarta: Program Studi Pendidikan Biologi, FKIP Universitas Sebelas Maret. Retrieved from https:// media.neliti.com/media/publications/1763 19-ID-none.pdf

Oftika, E., Jalmo, T., \& Marpaung R, R. (2015). Pengaruh intensitas mengakses internet terhadap hasil belajar biologi pada konsep ekosistem. Jurnal Bioterdidik, 3(8), 1-8. Retrieved from http://jurnal.fkip.unila.ac. id/index.php/JBT/article/view/9556

Pantiwati, Y., \& Permana, F. H. (2017). Analisis butir soal oleh mahasiswa S1 pendidikan biologi Universitas Muhammadiyah Malang (UMM) berdasarkan PISA dan taksonomi bloom revisi. In Seminar Nasional Pendidikan Berkemajuan dan Menggembirakan (The Progressive \& Fun Education Seminar) ke-2 (pp. 707-716). Surakarta: Universitas Muhammadiyah Surakarta.

Pantiwati, Y., Wahyuni, S., \& Permana, F. H. (2017). Instructional model of natural science in junior high schools, batu malang. Journal of Education and Practice, 8(8), 117-123. Retrieved from https://files.eric.ed.gov/fulltext/EJ1139066 
.pdf

Permana, F, H., \& Listawati, R, M. (2016). Peran perpustakaan sekolah dalam memfasilitasi siswa belajar biologi. In Prosiding Seminar Nasional II Tahun 2016, Kerjasama Prodi Pendidikan Biologi FKIP dengan Pusat Studi Lingkungan dan Kependudukan (PSLK) Universitas Muhammadiyah Malang (pp. 1194-1204). Malang: UMM Press.

Permana, F. H. (2015). Pengembangan buku ajar biologi berbasis blended learning sebagai bekal hidup di abad 21 untuk mahasiswa S1 kimia FMIPA UM. In Prosiding Seminar Nasional Pendidikan Biologi 2015, yang diselenggarakan oleh Prodi Pendidikan Biologi FKIP Universitas Muhammadiyah Malang, tema: "Peran Biologi dan Pendidikan Biologi dalam Menyiapkan Generasi Unggul dan Berdaya Saing Global", Malang, 21 (pp. 50-61). Malang: Universitas Muhammadiyah Malang.

Purwanti, E., \& Permana, F, H. (2018). Penerapan (STAD) dipadu dengan mind mapping berbasis lesson study untuk meningkatkan motivasi dan pemahaman konsep siswa kelas IX di SMP Muhammadiyah 6 Malang. Jurnal Inovasi Pembelajaran, 4(1). hhttps://doi.org/10.2 2219/jinop.v4i1.4955

Ramadani, S. D., Fauzi, A., Sukmawati, I., \& Corebima, A. D. (2015). Perbandingan potensi strategi pembelajaran cooperative script dan reciprocal teaching dalam memberdayakan keterampilan metakognitif, hasil belajar Biologi, dan retensi siswa SMA. In Proceedings of the 2nd Seminar \& Workshop Nasional Biologi, IPA, dan Pembelajarannya FMIPA UM (pp. 655-661). Malang: Biologi FMIPA UM.

Rashid, Z. A., Kadiman, S., Zulkifli, Z., Selamat, J., \& Hashim, M. H. M. (2016). Review of web-based learning in TVET: history, advantages and disadvantages. International Journal of Vocational Education and Training Research, 2(2), 7. https://doi.org/10.11648/j.ijvetr.20160202. 11

Razak, R. A., \& Hua, K. B. (2012). Self regulated learning for developing nursing skills via web-based. The Malaysian Online Journal of Educational Science, 1(1), 43-54. Retrieved from https://files.
eric.ed.gov/fulltext/EJ1086255.pdf

Rehatta, B. (2014). Frase preposisi dalam artikel jurnal akademik pada english teaching forum volume 41, no.4, tahun 2003. Universitas Sam Ratulangi.

Saad, N. (2004). Criteria for the review of digital learning materials.

Saini, K., Abdul, W., \& Purohit, G. . (2014). Traditional learning versus web based learning: Performance analysis. International Journal of Computer Science and Information Technologies, 5(4), 5182-5184. Retrieved from http://ijcsit.com/docs/Volume5/vol5issue0 4/ijcsit2014050479.pdf

Salyers, V. L. (2007). Teaching psychomotor skills to beginning nursing students using a web-enhanced approach: a quasiexperimental study. International Journal of Nursing Education Scholarship, 4(1), 1-12. Retrieved from https://pdfs.semantic scholar.org/79c2/fa18779ceab1b9659e3ba 8c95bc5ad818444.pdf

Sanjaya, W. (2012). Media komunikasi pembelajaran. Jakarta: Kencana Prenada.

Schunk, D. H., Meece, J. L., \& Pintrich, P. R. (2015). Motivation in education: theory, research and applications. Essex: Pearson Education Limited.

Shaimah, S. (2016). Pengembangan media pembelajaran biologi web statis berbasis adobe dreamweaver pada materi virus untuk siswa SMA/MA Kelas X. Fakultas Sains dan Teknologi.

Sihombing, D. (2015). Tipografi dalam desain grafis. Jakarta: Gramedia Pustaka Utama.

Sudjana, N. (2017). Penilaian hasil proses belajar mengajar. Bandung: PT Remaja Rosdakarya.

Sukmawati, I., Ramadani, S. D., Fauzi, A., \& Corebima, A. D. (2015). Perbedaan pemberdayaan retensi antara siswa SMA akademik rendah dan tinggi melalui pembelajaran cooperative script dalam pembelajaran biologi. In Proceedings of the 2nd Seminar \& Workshop Nasional Biologi, IPA, dan Pembelajarannya FMIPA UM (pp. 662-667). Malang: Biologi FMIPA UM.

Thiagarajan, S., Semmel, D, S., \& Semmel, M, I. (1974). Instructional development for training teachers of exceptional children: a sourcebook. Bloomington, Indiana: Indiana University.

Wahyuni, E., \& Muttaqin, S. M. (2018). 
Hidayah et al. / JPBI (Jurnal Pendidikan Biologi Indonesia) / 4 (2) (2018) pp.179-188

Teaching english with an internet-based of google docs to improve student's critical thingking. Medwell Journals, 13(4), 808812. https://doi.org/http://dx.doi.org/10.39 23/sscience.2018.808.812

Widiansyah, A. T., Indriwati, S. E., Munzil, \& Fauzi, A. (2018). I-invertebrata as an android-based learning media for molluscs, arthropods, and echinoderms identification and its influence on students' motivation. JPBI (Jurnal Pendidikan Biologi Indonesia), 4(1), 4352.https://doi.org/10.22219/jpbi.v4i1.5476 